Лингвоэкспертология

УДК 81'272, ББК 81.5, ГСНТИ 16.31.61, КОД ВАК 10.02.01

\title{
Семантика слов с элементомчерн- и их оценка при проведении лингвистической экспертизы (на материале комментариев интернет-пользователей)
}

\author{
Т.В. Бердникова
}

ФБУ Саратовская лаборатория судебной экспертизы Министерства юстиции Российской Федерации 410028, Саратов, ул. Вольская, 11a, к.155. E-mail: sintax2@yandex.ru

\begin{abstract}
Рассматриваются особенности семантики слов с элементом черн-. Анализу подвергаются слова с данным элементом разных частей речи: имена существительные, имена прилагательные. Внимание уделяется функционированию данных слов в интернет-коммуникации, рассматриваются особенности интернет-комментария как жанра. В статье выявляются особенности анализа слов с элементом черн- в аспекте судебной экспертизы, рассматриваются проблемы экспертной оценки и квалификации данных слов. Анализируются материалы по делам, связанным с противодействием экстремизму. В статье представлена специфика лингвистического анализа данных материалов с учетом коммуникативной ситуации и особенностей материала.
\end{abstract}

Ключевые слова: лингвистическая судебная экспертиза; комментарии; речевое взаимодействие; семантический анализ

\section{The semantics of words with the constituent chern- and their assessment when implementing a linguistic expertise (based on the comments of Internet users)}

\author{
T.V. Berdnikova \\ Saratov Laboratory of Forensic Science of the Ministry of Justice of the Russian Federation \\ 410028, Saratov, ul. Volskaya 11, k.155. E-mail: sintax2@yandex.ru
}

\begin{abstract}
The features of the semantics of words with the constituent chern -are considered. Words with this constituent belonging to different parts of speech are analyzed: nouns, adjectives. Attention is paid to the functioning of these words in the Internet communication, the features of Internet commentary as a genre are considered. The article reveals the peculiar features of the analysis of words with the element of chern-in relation to forensic examination, considers the problems of expert assessment and qualification of these words. Case papers connected with counteraction to extremism are analyzed. The article presents the specifics of linguistic analysis of thesepapers, taking into account the communicative situation and peculiarities of the mat erial. Key words: forensic linguistics; comments; verbal interaction; semantic analysis

Современная лингвистическая экспертиза исследуетмножество объектов: письменные и устные тексты, креолизованные тексты, электронные тексты. Последний вид представляет собой различные жанры, одним из которых является комментарий пользователей сети Интернет. В основном комментарии ста новятся объе ктами лингвистиче ской экспертизы по делам, связа нным с противодействием экстремизму.

Особенности интернет-коммуникации обусловлива ют характер общения ее уча стников. К таким особенностям можно отнести следующие: 1. анонимность, которая обусловливает аффе ктивную раскрепощенность, ненормативность и не которую безответственность участников общения; 2. невозможность использования (либо сведение к минимуму) невербальных средств; 3. добровольность и желательность контактов; 4. затрудненность эмоционального компонента общения и в то же время стойкое стремление к эмоциональномунапряжению текста; 5. легкая смена формальныхатрибутов идр. [Мина ков 1999; Шевченко 2007].

Комментарии имеют двойную адресованность: непосредственный адресат, на чье сообщение отвечает автор те кста, и не огра ниченный круг лиц (поскольку комментарии доступны любому пользователю сети Интернет), т.е. массовый а дресат.
\end{abstract}


В комментариях в социальных сетях, на новостных сайтах, в блогах и чатах происходит обсуждение «наболевших» социальных проблем. К числута ких проблем относится экстремизм. Особого внима ния заслужива ет но минация групп лиц по их на циона льной и/или расовой принадлежности - «хачи», «чурки», «чёрные»ит.п.

В материалах, содержащих обсуждение статей, видеороликов, фильмов, аудиозаписей, представлено большое число лексем с элементом черн- (чёрный, черномазый, черножопый, чернота, чернильница и др.).

В Новом словообразовательном словаре русского языка А.Н. Тихонова [Тихонов 2014] с элементом черн- представлена достаточно разветвленная система слов, связанных отношениями разного типа. В экспертной практике в основ ном мы сталкиваемся с та кими словами, ка кчёрный, черномазый, черножопый, чернота. Все эти слова содержатобщий корень черн-, значение которого лежит в основе толкования вышеприведенных слов. По замечанию Г.О. Винокура, «не прямое описание соответствующего предмета действите льности и составляет собственно лингвистическую задачу в изучении значений слов» [Винокур 1959: 421].

Корневым словом для лексем черномазый, черножопый, чернота является слово чёрный. Оно образовано путем субста нтивации и является узуа льным субста нтиватом, к числу которых относятся слова адъективного типа (прилагательные, причастия, местоименияприла га тельные, порядковые числительные) [Высоцкая 2014: 328]. Пользуясь типологией субста нтивации, предложенной И.В. Высоцкой, можно отнести да нное слово к типу конте кстуальной субста нтива ции, за крепленной в определенных контекстных условиях.

В словарях общеупотребительной лексики представлены следующие де финиции слова чёрный (при коммуникативной ситуа ции обозначения ка ких-либо лиц):

чЁРНЫЙ. 2. // Разг. Смуглый и черноволосый. 3. Имеющий темный цвет кожикак признак негроидной расы [Большойтолковый словарь русского языка 2000: 1474].

чЁРНЫЙ. Только полн. ф. Темнокожий (как признак расы) [Словарь русского языка 1998: 667].

В словарях общеупотребительной лексики слово чёрный содержит указа ние на внешние признакичеловека (цветкожи, волос), не содержит указание на отношение говорящего к лицам, обозначаемым данным словом (чёрные), представлено нейтральное значение.

Этимологический словарь А.К. Шапошникова также не дает отрицательных оценок в значении этого слова (ЧЁРНЫЙ. полн. ф. $c$ темной кожей (как призна к расы), чернокожий [Этимологический слова рь современного русского языка 2010: 2, 521].

Одна ко в комментариях, являющихся объектом исследования, слово чёрный имеет не гативные ха рактеристики:

(1) Порой поражаюсь с этих чёрных ублюдков.

(2) А тыготов к борьбе за расу? Погоним чёрных! Ой, ой!

(3) Изабудь про жалость. Чёрный это мразь!

(4) Чёрного увидишь - в рожу бей с ноги!

(5) Терпенью конец - нужно чёрных валить!

(6) Просто надо своим детям с детства прививать как надо этих чёрных на место ставить вот и все.

Во всех примерах слово чёрный отражает негативное, враждебное отношение говорящего к группе лиц, названной чёрные. По отношению к данной группе гово рящими используются слова ублюдки, мразь. Кроме того, обозначены действия, которые необходимо совершить по отношению к группе чёрные: погоним чёрных, в рожу бей с ноги, забудь про жалость (по отношению к чёрным), нужно чёрных валить, чёрныхна место ставить.

Эти негативные ха рактеристики указаны в словарях субстандартной лексики:

чЁРНЫЙ. 1. (чаще мн. чёрные). Уничиж. (презр.) Разг. -сниж. О людяхс темным, смуглым цветом кожи; о кавказцах или о выходцах из некоторых азиатских стран [Химик 2004].

ЧЁРНЫЙ. 1. (чаще мн. чёрные). Фам. Уничижит. О людях с темным, смуглым цветом кожи; о кавказцах или о выходцах ив некоторых азиа тских и а фрика нских стран ( черномазый) [Химик 2017: 2, 460].

Как видно из последних толкований, слово чёрный, помимо приобретения негативных коннотаций, выраженных в словарных пометах уничижительное, фамильярное, содержит указание на принадлежность обозначенных этим словом лиц к кавказскому, азиатскому, а фриканскому регионам.

Негативное отношение говорящих к народам из кавказского, азиатского, африканского регионов обусловливает использование слова чёрный с отрицательными коннотациями. Имеет место расширение значения слова чёрный, выражены отношения метафорической мотивации, когда слово мотивировано непрямым значением (Ср. чёРныЙ. 7. Не вызывающий одобрения, предосудительный; низкий, кова рный, подлый [Большойтолковый словарь русского языка 2000: 1474]).

Производное от слова чёрный лексема черномазый, изначально не имевшая отрицательных коннотаций, также приобретает семантическое приращение негативного отношения к группе лиц, названных черномазые:

Всехчерномазых в кровавый фрарш!

В Словаре русского языка под редакцией Евге ньевой [Словарь русского языка] представлено нейтральное толкование слова черномазый с указа нием на внешностьчеловека:

ЧЕРНОМАЗЫЙ. 1. Черноволосый и смуглый [Словарь русского языка 1998: 4, 666].

В словаре под редакциейС.А. Кузнецова слово черномазый имеет помету презрительное:

ЧЕРНОМАЗЫЙ. 1. Презрит. Черноволосый и смуглый (обычно по отношению к представителям южных национальностей, неграм, цыганам ит.п.) [Большойтолковый словарь русского языка 2000: 1474]

В словарях субста ндартной лексики это слово имеет пометы сниженное, грубое, уничижительное:

ЧЕРНОМАЗЫЙ. Сниж. Груб. Уничиж. Чернокожий илис очень темной кожей, черноволосыйчеловек (о негроидах, реже о южанах, азиатах, цыганах) [Химик 2017: 2, 457].

В последних двух случаях в толковании появляется указание на национальность и регион.

В Толковом слова ре русской разговорно-обиходной речи [Химик 2017] слово черномазый сема нтически связывается со словами чёрный, черножопый, чернота.

Слово черножопый употребляется следующих контекстах:

(1) Бей черножопых! Бей заразу!

(2) Черножопым вход запрещен.

Слово черножопый обра зовано способом сложения основ (черн+жоп), имеет прозрачную внутреннюю форму.

ЧЕРНОЖОПЫЕ. Грубо. 1. Негры. 2. О жителях Средней Азии или Кавказа [Большой толковый словарь русского языка 2000: 1473].

ЧЕРНОЖоПЫЙ. Сниж. Груб. Бран. О любом темнокожем или очень смуглом человеке; о выходце из Ка вказского региона или из южноа зиатских и африка нских стран, о негроиде ( черномазый) [Химик 2017: 2, 457].

Таким образом, в толковании данного слова содержится описание внешности и указание на расу, место жительства. 
Еще одним словом, связанным с корнем черн-и образованным от слова чёрный, является слово чернота.

Славянский народ, поднимайся с колен,

Поднимайся и бей ради наших детей,

Ради нашей земли, поднимайся и стой,

Зачищая тылы-чернотуза спиной.

Значение слова чернота, указывающее на отношение к каким-либо лицам, представлено в словаре под ред. В.В.Химика:

ЧЕРНОТА. Собир. Сниж. Пренебр. О людях со смуглой кожей, иногда о жителях Кавказа или азиатских стран ( черномазый) [Химик 2017: 2, 457].

В данной дефиниции содержится ука зание на описание внешности и обозначение места жительства.

Та ким обра зом, согласно толкованию в словаре подред. В.В. Химика [Химик 2017], слова чёрный, черножопый, чернота являются сема нтически близкими, нередко контекстуально синонимичными. В своем значении эти слова содержат не только указание на внешние призна кичеловека, но ина его прина длежность к определенной национальности, обозначение места жительства ив некоторых случа ях расы.

В комментариях интернет-пользователей нередко общеупотребительные слова используются в несвойственном значении. Так, слово чернильница в современном русском языке имеет следующее значение: 2000: 1473]

ЧЕРНИЛЬНИЦА. Специа льный сосуд для чернил, в который ма кают перо, когда пишут [Большой толковый словарь русского языка

Однако в комментариях это слово употребляется в ином значении:

(1) Этоже чернильницы. Чтос них взять!

(2) Позор матерям, которые воспитывают такихчернильниц!

(3) Требую расстрелять таких икур чернильниц

(4) Хотя чернильничу, тоже не жалко. Нечего было с чуркой путаться.

Как видно из контекста, слово чернильница означает лицо женского пола, причем такая женщина/девушка оценивается негативно, посколькупо отношению к ней предлагается применить враждебные на сильственные действия.

Слово чернильница в данном употреблении мотивировано словом чёрный в значении 'О людях стемным, смуглым цветом кожи; о кавказцах или о выходцах из некоторых азиатских стран'. Следует отметить, что слово чернильница мотивировано словом чернила ('красящая жидкость для писания'). Изначально чернила имели черный цвет, однако впоследствии для письма стали использоваться чернила другихцветов.

Таким образом, можно определить значение слова чернильница следующим образом:

ЧЕРНИЛЬНИЦА. Женщина/девушка, имеющая сексуальные отношения с мужчинами, принадлежащими к группе чёрные, т.е. к группе лиц, имеющих темный, смуглый цвет кожи; являющихся кавказцами или выходцами из азиатских иа фриканских стран.

В результате такого употребления слово чернильница приобретает отрицательную коннотацию.

Та ким обра зом, семантика слов с элементом черн- обусловлена контекстом их функционирования. При экспертной оценке таких слов необходимо проводить многоаспектный анализ, включающий контекстный ана лиз, а также учитывающий общую коммуникативную ситуацию.

\section{Литература}

1. Большой толковый словарь русского языка / Сост. и гл. ред. С.А. Кузнецов. Спб., 2000.

2. Винокур Г.О. Заметки по русскому словообразованию // Винокур Г.О. Избранные работы по русскому языку. М., 1959. С. 419 -442.

3. Высоцкая И.В. Типы субстантивации и типы речевого поведения // Русский язык: исторические судьбы и современность: V Междунар. Конгресс исследователей русского языка (18-21 марта 2014 г.): Труды и материалы. М., 2014.

4. Кукушкина О.В., Сафонова Ю.А., Секераж Т.Н. Методика проведения судебной психолого-лингвистической экспертизы материалов по делам, связанным с противодействием экстремизму и терроризму. М., 2014.

5. Минаков А.В. Некоторые психологические свойства и особенности Интернета как нового слоя реальности. 1999. http://flogiston.ru/articles/netpsy/minakov/.

6. Словарь русского языка: В 4-х т. Т. 4. М., 1998

7. Тихонов А.Н. Новый словообразовательный словарь русского языка для всех, кто хочет быть грамотным. М., 2014.

8. Химик В.В. Большой словарь русской разговорной экспрессивной речи. СПб., 2004.

9. Химик В.В. Толковый словарь русской разговорно-обиходной речи: В 2 т. Т. 2. СПб., 2017.

10. Шевченко И. (2007). Некоторые психологические особенности общения посредством Internet. URL: http://flogiston.ru/articles/netpsy/shevchenko/.

11. Этимологический словарь современного русского языка: В 2 т. Т. 2. М, 2010.

\section{References}

1. Chimik, V.V. (2004). Large Dictionary of Russian colloquial expressive vocabulary [Bolshoi slovar russkoi razgovornoi ekspressivnoi l eksiki]. Saint Petersburg (in Russian).

2. Chimik, V.V. (2017). Explanatory Dictionary of Russian colloquial speech [Tolkovyi slovar russkoj obihodno-razgovornoj rechi]. Vol. 2. Saint Petersburg (in Russian).

3. Dictionary of the Russian language. (1998). [Slovar russkogo yazyka]. Vol. 4. Moscow (in Russian)

4. Etymological dictionary ofthe modern Russian language. (2010). [Etimologicheskijslovarsovremennogorusskogoyazyka]. Vol. 2. Moscow (in Russian)

5. Kukushkina, O.V., Safonova Yu. A., Sekerazh T.N. (2014). The methodology of the forensic psycho-linguistic examination of cases related to counteraction to extremism and terrorism [Metodika provedeniya psikhologo-lingvisticheskoy ekspertizy materialov po delam, svyzannym s protivodeystviem ekstremismsu I terrarizmu]. Moscow (in Russian).

6. Large Explanatory Dictionary of the Russian Language. (2000). [Bolshoi tolkovyi slovar russkogo yazyka]. Saint Petersburg (in Russian).

7. Minakov, A.V. (1999). Some psychological properties and features of the Internet as a new layer of reality [Nekotoryje psykhologicheskije svojstva I osobennosti Interneta kak novogo sloja realnosti]. Available from: http://flogiston.ru/articles/netpsy/minakov/Accessed 10.05 .2019 (in Russian)

8. Shevchenko, I. (2007). Some psychological features of communication via the Internet [Nekotoryje psykhologicheskije osobennosti obschenija posredstvom Internet]. Availavble from: http://flogiston.ru/articles/netpsy/shevchenko/ Accessed 10.05.2019 (in Russian) 
9. Tikhonov, A.N. (2014). New word-formation dictionary of the Russian language for everyone who wants to be literate [Novyj slovoobrazovatelnj slovar russkogo yazyka dlya vseh kto hochet byt gramotnym]. Moscow (in Russian).

10. Vinokur, G.O. (1959). Notes on Russian word formation [Zametki po slovoobrazovaniju] (Pp. 419-442). In: Selected works on the Russian language [Izbrannyje raboty po russkomu yazyku]. Moscow (in Russian).

11. Vysotskaja, I.V. (2014). Types of substance and types of speech behavior [Tipy substantivatcii I tipy rechevogo povedenija]. Russi an language: historical destiny and present. Proceed. $V$ int. Congress of Russian language researchers (18-21 March 2014): Proceedings and materials [Russkij yazyk: istoricheskije sudby I sovremennost: V Mezhdunarodnyj Kongress issledovatelej russkogo yazyka: Trudy I materialy]. Moscow (in Russian).

\section{Citation:}

Т.В. Бердникова. Семантика слов с элементомчерн-и их оценка при проведении лингвистической экспертизы (на материале комментариев интернетпользователей) // Юрислингвистика.-2019. -№12.-С. 20-23.

Berdnikova, T.V. (2019). The semantics of words with the constituent chern- and their assessment when implementing a linguistic expertise

(based on the comments of Intemet users). Legal Linguistics, 12, 20-23.

(c) EY 